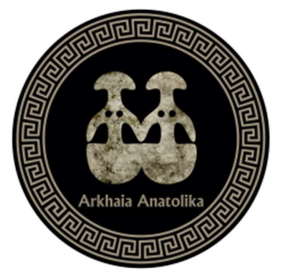

\author{
Arkhaia Anatolika \\ Anadolu Arkeolojisi Araştırmaları Dergisi \\ The Journal of Anatolian Archaeological Studies
}

Volume 4 (2021)

\title{
Aydın Arkeoloji Müzesi'ndeki Menderes Antiokheiası Buluntusu Heykeltıraşlık Eserleri
}

\author{
Sculpture Artifacts from Antioch on the Maeander in the Aydin \\ Archaeological Museum
}

\section{Umut KAPUCi்}

iD https://orcid.org/0000-0001-8550-6091

Geliş Tarihi: 06.06.2021 | Kabul Tarihi: 04.07.2021 | Online Yayın Tarihi: 11.07.2021

Makale Künyesi: Kapuci, U. (2021). Aydın Arkeoloji Müzesi'ndeki Menderes Antiokheiası Buluntusu Heykeltıraşlık Eserleri. Arkhaia Anatolika, 4, 256-268. https://doi.org/10.32949/Arkhaia.2021.35
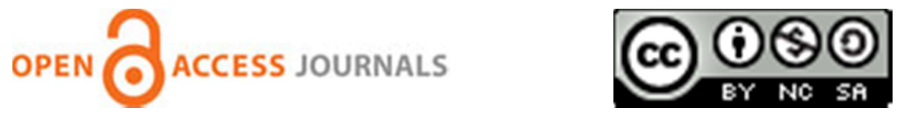

Arkhaia Anatolika, Anadolu Arkeolojisi Araştırmaları Dergisi "Açık Erişimli" (Open Access) bir dergidir. Kullanıcılar, dergide yayınlanan makalelerin tamamın tam metin olarak okuyabilir, indirebilir, makalelerin çıktısını alabilir ve kaynak göstermek suretiyle bilimsel çalışmalarında bu makalelerden faydalanabilir. Bunun için yayıncıdan ve yazar(lar)dan izin almasına gerek yoktur.

Dergide yayınlanan makalelerin bilimsel ve hukuki sorumluluğu tamamen yazar(lar)ına aittir.

Arkhaia Anatolika, The Journal of Anatolian Archaeological Studies follows Open Access as a publishing model. This model provides immediate, worldwide, barrier-free access to the full text of research articles without requiring a subscription to the articles published in this journal. Published material is freely available to all interested online readers.

The scientific and legal propriety of the articles published in the journal belongs exclusively to the author(s). 


\title{
Aydın Arkeoloji Müzesi'ndeki Menderes Antiokheiası Buluntusu Heykeltıraşlık Eserleri
}

\author{
Sculpture Artifacts from Antioch on the Maeander in the Aydin Archaeological \\ Museum
}

\author{
Umut KAPUCí
}

\begin{abstract}
Öz
Bu çalışmada, günümüzde Aydın Arkeoloji Müzesi Taş Eserler Deposu'nda korunan ve müzeye satın alma yoluyla kazandırılan iki büst ve bir kabartma parçası ele alınmıştır. Amaç, Karia Bölgesi'nin Hellenistik ve Roma İmparatorluk Dönemi heykeltıraşlık literatürüne katkı sağlayarak, eserleri bilim dünyasına sunmaktır. Bu doğrultuda Menderes Antiokheiası'nda bulunan plastik eserlerin tipoloji ve stil özellikleriyle birlikte, buluntuların ait olduğu dönem özellikleri ve heykeltıraşlık merkezleri belirlenmeye çalışılmıştır. Daha önce Menderes Antiokheiası antik kenti ile ilgili Aydın Arkeoloji Müzesi'nde korunan ve araştırmacılar tarafından Aphrodisias antik kenti girlandlı lahitler grubu içerisinde değerlendirilen ve girland taşıyıcısı olarak Herakles Hermesinin betimlendiği bir lahit parçası dışında herhangi bir heykeltıraşlık eserinin yayınlanmamış olması, bu çalışmanın özgünlüğünü göstermektedir. Eserler kazı malzemesi olmaması ve buluntu durumu ile ilgili envanter kayıtlarında bilgi bulunmaması nedeniyle genel olarak Karia Bölgesi ve yakın coğrafyadaki Hellenistik ve Roma İmparatorluk Dönemi heykeltıraşlık eserleriyle analoji yoluyla tarihlenebilmiştir. Araştırma içeriğini oluşturan iki büst parçasından ilk örnek Roma İmparatorluk Dönemi içerisinde MS 1. yüzyılın ikinci yarısının dönem modasını, ikinci örnek MS 2. yüzyıl sonlarının stil özelliklerini yansıtmaktadır. Üçüncü ve son örneği oluşturan kabartma parçası için ise Hellenistik Dönem Pergamon ekolü etkisi altında MÖ 2. yüzyılın ilk yarısı önerilmektedir. Yapılan karşılaştırmalar sonucunda buluntuların Pergamon, Aphrodisias, Tralleis ve Stratonikeia gibi yakın merkezlerdeki eserlerin stil özelliklerini yansıttı̆̆ı görülmektedir.
\end{abstract}

Anahtar Kelimeler: Karia Bölgesi, Menderes Antiokheiası, Hellenistik ve Roma İmparatorluk Dönemi, Heykeltıraşlık, Büst, Kabartma

\section{Abstract}

In this study, two busts and a relief fragment, which are preserved in the Stone Artifacts Warehouse of Aydin Archaeological Museum and brought to the museum through purchase, are discussed. The study aims to bring these artifacts into discussion and thereby contribute to the sculpture literature of the Hellenistic and Roman Imperial Periods of the Caria Region. To this end, the researchers determined the typology and style features of the plastic works found in Antioch on the Maeander, as well as the period features and sculpture centers of the finds. The originality of the study is reified by the fact that no studies on sculptural works have been published, except for a sarcophagus fragment depicting the Heracles Herme as the bearer of the garland, which was previously preserved in the Aydin Archaeological Museum related to the ancient city of Antioch on the Maeander and evaluated by the researchers in the group of sarcophagi with garland of the ancient city of

\footnotetext{
* Arkeolog Umut Kapuci, Aydın Adnan Menderes Üniversitesi, Sosyal Bilimler Enstitüsü, Arkeoloji Anabilim Dalı, Doktora Programı, Aydın/TR. E-mail: ukapuci@gmail.com / Orcid iD: 0000-0001-8550-6091

Bu çalışma, Aydın Adnan Menderes Üniversitesi, Sosyal Bilimler Enstitüsü, Arkeoloji Anabilim Dalı Doktora programında, Doç. Dr. Murat Çekilmez danışmanlığında yürütülen “Aydın Arkeoloji Müzesi Örnekleriyle Karia Bölgesi Heykeltıraşlığı” adlı Doktora Tezinden türetilmiştir. Söz konusu tez çalışması, FEF-19015 numaralı proje ile ADU Bilimsel Araştırma Projeleri birimi tarafından desteklenmiştir. Destekleri için Aydın Adnan Menderes Üniversitesi Rektörlüğü'ne ve ADU BAP Birimine teşekkür ederim. Aydın Arkeoloji Müzesi'ndeki eserlerin izin ve destekleri nedeniyle Müze Müdürü Arkeolog Abdülbari Yıldız, Arkeolog Yılmaz Akkan, Arkeolog Funda Ertuğrul ve Arkeolog Şenay Çekilmez'e, çalışmalar sırasındaki yardımları nedeniyle Arş. Gör. Emrah Özdemir, Arkeolog Kemal Ersavaş ve Arkeolog Fevzi Özcan'a teşekkür ederim.
} 
Aphrodisias. Since the artifacts are not excavated materials and there is no information in the inventory records about the find context, they were dated by analogy with the Hellenistic and Roman Imperial Period sculpture works in the Caria Region and the nearby geography. The first example of the two bust fragments that make up the research content reflects the fashion of the second half of the 1st century AD in the Roman Imperial Period, and the second example reflects the style characteristics of the end of the 2 nd century AD. The first half of the 2 nd century BC, under the influence of the Hellenistic Period Pergamon School, is suggested for the relief fragment, which constitutes the third and final example. As a result of the comparisons, it is seen that the finds reflect the stylistic features of the works in nearby centers such as Pergamon, Aphrodisias, Tralleis and Stratonikeia.

Keywords: Caria Region, Antioch on the Maeander, Hellenistic and Roman Imperial Period, Sculpture, Bust, Relief

\section{Giriş}

Karia Bölgesi sinırları içerisinde yer alan Menderes Antiokheiası yerleşiminde şimdiye kadar, kısa süreli arkeolojik yüzey araştırmaları dışında herhangi bir kazı çalışması yapılmamıştır. İlk olarak 1775 yılında R. Chandler, Ephesos'tan doğuya, Antiokheia' ya kadar uzanan büyük bir yoldan bahsetmiştir1․ Bu yol özellikle Roma İmparatorluk Dönemi'nde doğudan batıya uzanan ticari ve askerî açıdan stratejik bir konum üzerinde yer almaktadır. Daha sonra 1824 yılında W. M. Leake, kentin coğrafi konumunun yanı sıra Ephesos'tan başlayıp Mazuka'ya giden “Büyük Doğu Yolu”ndan bahsettiği çalışmasında, söz konusu yolun Morsynos Nehri üzerindeki antik köprüden ve bu köprü üzerinden Antiokheia'dan geçerek Karoura ve Laodikeia'ya ulaştı̆̆ını aktarmaktadır². Araştırmacı, R. Chandler'in belirttiği bu rotayla ilgili daha kapsamlı bilgiler vermiştir. 1842 yılında W. J. Hamilton, Menderes Antiokheiası kalıntıları arasında, akropolis surları, iç kale, stadion ve küçük ölçekli tiyatronun skene ve proskene bölümlerinden bahsetmektedir ${ }^{3}$. Bu nedenle kentin kalıntılarını tanımlama açısından W. J. Hamilton'un verdiği bilgiler oldukça önemlidir. Bu bölgede uzun yıllardır araştırmalar yürüten Aphrodisias kazısı başkanı R. R. R. Smith ile C. Ratté, 1994 yılında Menderes Antiokheiası'nda arkeolojik yüzey araştırmaları gerçekleştirmiştir4. Araştırmacılar, yüzey araştırmasının sonuçlarını içeren çalışmada; Roma İmparatorluk Dönemi savunma mimarisi ve doğu-batı doğrultulu, yaklaşık $200 \mathrm{~m}$ uzunluğundaki stadion ile ilgili bilgiler aktarmaktadır. Özellikle son yıllardaki arkeolojik gelişmelerle birlikte kentin yeniden ele alınması, yerleşim hakkındaki bilgilerimizin artmasını sağlamıştır. 2011 yılında R. Dinç, Menderes Antiokheiası antik kenti yakınındaki Roma İmparatorluk Dönemi'ne tarihlenen köprüyü, topografik ve jeo-stratejik konumu açısından değerlendirmiştir ${ }^{5}$. Bu çalışmayla kentin stratejik konumu ve Roma İmparatorluk Dönemi yapıları konusundaki bilgilerimiz artmıştır. 2012 yılında ise A. Saraçoğlu ve H. Üreten, kentin tarihsel coğrafyasına değindikleri çalışmalarında akropolis ve yamaç yerleşimlerine ait yapı kalıntıları ile ilgili bilgiler aktarmışlardır' ${ }^{6} 2017$ yılında R. H. Söner, kentin tarihi coğrafyasının yanı sıra sikke darbı, sur, tiyatro, stadion ve köprü gibi mimari kalıntıları ve nekropolis alanını içeren bir çalışma gerçekleştirmiştir7. Sözü edilen bu çalışma son yıllarda kentle ilgili en kapsamlı yayındır. Kuruluşu Hellenistik Dönem'e dayanan kentin bu dönemi ile ilgili herhangi bir bilgi bulunmamasına karşın, burada değerlendirilen kabartma parçası, kentte Hellenistik Dönem'de plastik buluntuların var olduğunu göstermiştir.

\footnotetext{
1 Chandler 1775, 207-210.

2 Leake 1824, 249.

${ }^{3}$ Hamilton 1842, 529-530.

4 Smith ve Ratté 1996, 21-24.

5 Dinç 2011, 111-128.

6 Saraçoğlu ve Üreten 2012, 88-89.

7 Söner 2017, 139-153.
} 
$\mathrm{Bu}$ çalışmada ele alınan üç plastik eser dışında günümüzde Aydın Arkeoloji Müzesi'nde korunan, 2656 envanter numaral1, girland taşıyıcısı olarak Herakles Hermesi betimlenen bir lahit parçası yer almaktadır (fig. 1). Söz konusu eserin müze envanter kayıtlarında Aydın ili, Kuyucak ilçesi, Başaran mahallesinden 16.05.1981 tarihinde müzeye getirildiği belirtilmektedir. Menderes Antiokheiası buluntusu olan bu lahit parçası, 1996 yılında V. M. Strocka ${ }^{8}$ ve 2007 yilında F. Işık ${ }^{9}$ tarafından Aphrodisias girlandlı lahitler grubunda incelenmiştir. Aynı eser, 2012 yılında N.

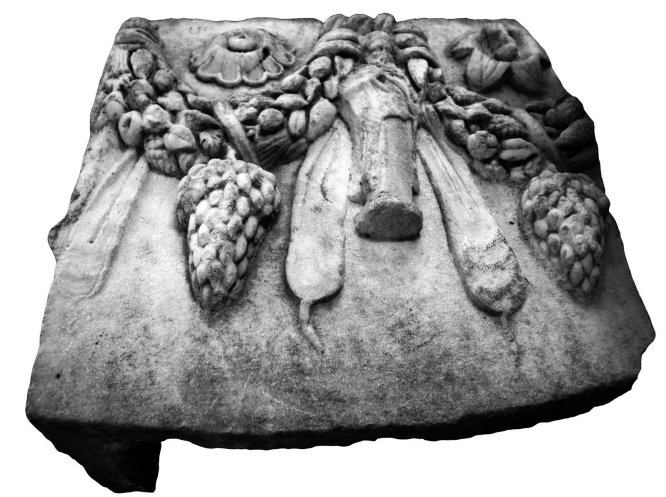

Figür 1: Aydın Arkeoloji Müzesi'nden Menderes Antiokheiası buluntusu lahit parçası Yıldırım ${ }^{10}$ tarafından Herakles Hermeleri öznelinde değerlendirilmiştir. Lahit parçası dışında kentin plastik eserleriyle ilgili herhangi bir araştırma bulunmamaktadır.

\section{Tipoloji ve İkonografi}

\section{Büst 1}

Çalışma kapsamında ele alınan ilk eser, bir erkek büstü parçasıdır. Menderes Antiokheiası buluntusu 1854 envanter numaralı örnek, Aydın ili, Kuyucak ilçesi, Başaran mahallesinde bulunmuş ve 20.05.1976 tarihinde satın alma yoluyla Aydın Arkeoloji Müzesi'ne kazandırılmıştır ${ }^{11}$. Orta grenli beyaz mermerden, dairesel kaide üzerinde, hafif sağına dönük, gövdenin üst kısmında köprücük kemiğine, alt kısmında ise göğüs altına kadar işlenmiş giysisiz büst, baş ve kaideyle birlikte tek bloktan yontulmuştur (fig. 2a-d). Baş, boynun biraz üzerinden kırık ve eksiktir. Sağ omuz ve göğsün kaide ile birleștiği nokta onarılmıştır. Gövde ve kaide üzerinde patina görülmektedir. Kolların işlenmediği büst; altta dairesel formlu, iki torus arasında derin bir trokhilos bulunan Ionik formda, tabulasız ve yazıtsız kaide üzerinde yer almaktadır.

Menderes Antiokheiası buluntusu, imparator büstlerinde erken örneklerden bilinen kılıç kayışı ve paludamentum ${ }^{12}$ ile betimlenmemiş olup, giysisiz olması nedeniyle imparator büstlerinin yanı sıra privat portre olarak gruplandırılan erkek büstleri içerisinde değerlendirilmiştir. Ayrıca kaide öznelinde değerlendirildiğinde; cephe ve profil teşhiri düşüncesini yansıtan biçimde ön kısımda izlenen torus silmelerinin yanlarda, gövde düzleminde yarı çapta kesilerek arka kısımda işlenmediği görülmektedir.

Lucius Cornelius Sulla13, Gaius Marius ${ }^{14}$ ve Augustus ${ }^{15}$ büstleri, köprücük kemiklerinin işlendiği erken örneklerdendir. Iulius Claudiuslar Dönemi büstleri, genellikle omuz başı ve kollar işlenmeden köprücük kemiklerine kadar betimlenmiştir ${ }^{16}$. Flaviuslar ${ }^{17}$ ve Traianus Dönemi18 büstlerinde köprücük kemiklerine kadar işlenen örnekler bulunsa da

\footnotetext{
8 Strocka 1996, 467, fig. 29.

${ }^{9}$ Işık 2007, kat. no. 28f, lev. 28-8.

10 Yıldırım 2012, 232, fig. 14.

11 Ölçüler: Y.: 43 cm, G.: 33 cm, K.: 12 cm, Kaide Y.: 12 cm, Kaide Ç.: 23 cm.

12 Smith 2008, 234-235.

13 Wünsche 2007, 126.

14 Wünsche 2007, 127.

15 Wünsche 2007, 132.

16 Pozzi 1989, 98, kat. no. 13; Smith 2008, 232-233.

17 Stuart-Jones 1912, 140, kat. no. 5; Smith 2008, 234-235; Fittschen et al. 2010, 65-66, kat. no. 60.

18 Wünsche 2007, 136, 137; Özgan 2013, 74, fig. 60.
} 
genel tipolojide omuzlarla birlikte gelişkin biçimde göğüs işlenişi görülmektedir. Bu tipoloji Hadrianus Dönemi'nde ${ }^{19}$ de sürdürülürken Antoninuslar Dönemi ve sonrasında büstler, genel olarak Hadrianus Dönemi özellikleri göstermesine rağmen, Commodus ${ }^{20}$ ve Gallienus Dönemi ${ }^{21}$ örneğinde olduğu gibi bel kısmına kadar kollar ile birlikte işlenen örnekler de bulunmaktadır. Tüm bu değerlendirmeler sşığında Menderes Antiokheiası buluntusu, Iulius Claudiuslar Dönemi erken büst örneklerinin genellikle bir portre yontusuna seperat yapılacak düzeyde omuzlardan aşağıya dar açılı inen konturu nedeniyle daralan kısa üst gövde ve yuvarlatılmış göğüs yapısının yanı sıra arka kısımlarının oyulmadan bırakılması ${ }^{22}$ geleneğine karşıt biçimde yüzyılın ikinci yarısında görülen biraz daha yükselmiş üst gövde ile nispeten gelişkin ve öne taşkın göğüs yapısı nedeniyle MS 1. yüzyılın ikinci yarısına ait olmalıdır. Benzer tipteki Aphrodisias Müzesi'nde yer alan ve MS 1. yüzyıl başlarına tarihlenen 5756 envanter numaralı Atrium Evi buluntusu Germanicus büstü²3, Smith'inn ${ }^{24}$ değindiği üzere Iulius Claudiuslar Dönemi erken büst örneklerinin temsili biçiminde dar tutulan omuz ve kısa üst gövde işlenişinin yanı sıra, arka kısmının oyulmadan bırakılması ve cepheden görülebilen destek nedeniyle Menderes Antiokheiası örneğine göre erken tarihli olmalıdır. Aphrodisias Müzesi'nde korunan ve MS 1. yüzyılın sonuna tarihlenen 79/10/156 envanter numaralı Hadrianus Hamamları buluntusu kılıç kayışlı büst²5, omuzlardan göğüs altına kadar işlenen üst gövde yapısı, göğsün yatay düzlemde arada bir tabula bulunmadan doğrudan Ionik formlu bir kaideye oturması ve diyagonal biçimde arkaya eğimli ${ }^{26}$ omurga desteğinin formu nedeniyle Menderes Antiokheiası yontusu ile çağdaş olmalıdır. Bodrum Arkeoloji Müzesi'nde yer alan ve MS 2. yüzyıla tarihlenen 4.4 .78 envanter numaralı Stratonikeia buluntusu erkek büstü̈ ${ }^{27}$, omuzların yanı sıra kolların üst kısmının da işlenmesi ve göğüs ile kaide arasında bulunan tabula ile Menderes Antiokheiası örneğinden daha geç olmalidir.

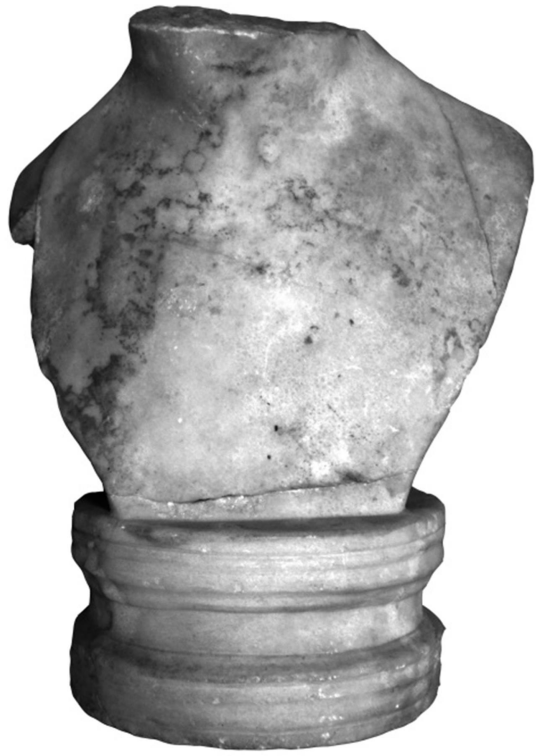

Figür 2a: Büst 1, ön yüz

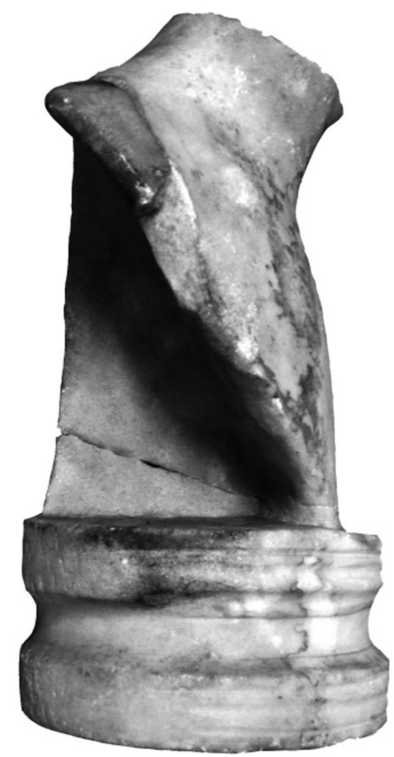

Figür $2 b$ : Büst 1, sağ profil

\footnotetext{
19 Lippold 1936, 207, kat. no. 593; Helbig 1963, kat. no. 27.

20 Fittschen ve Zanker 1985, 85 vd., kat. no. 78.

21 İnan ve Rosenbaum 1966, 188, lev. CXL, 1-2.

22 Smith 2008, 232.

23 Smith 2008, 232-233.

24 Smith 2008, 232.

25 Smith 2008, 234-235.

26 Smith 2008, 234.

27 Özgan 1999, 134-135, kat. no. K50.
} 


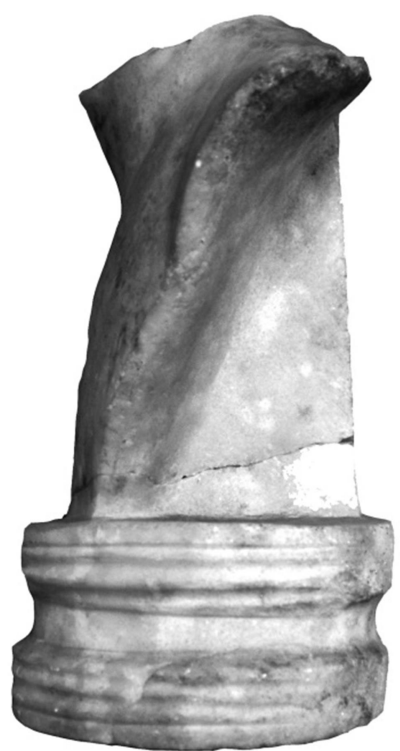

Figür 2c: Büst 1, sol profil

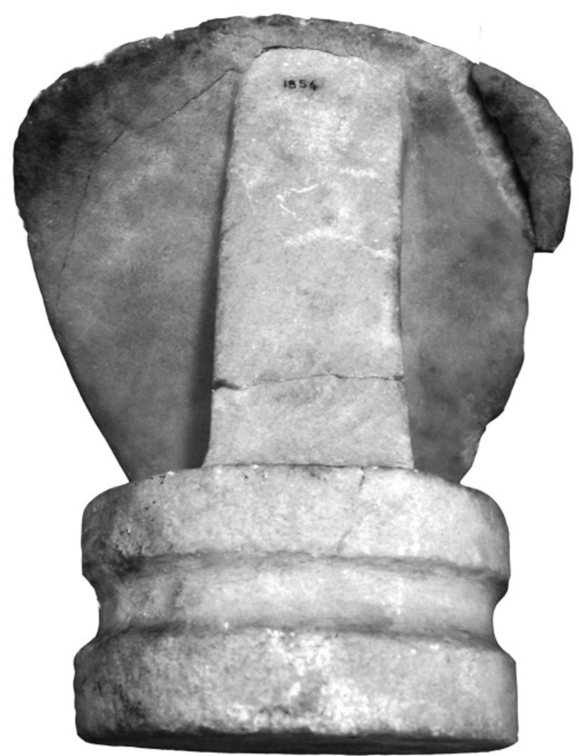

Figür 2d: Büst 1, arka yüz

\section{Büst 2}

Menderes Antiokheiası'ndan 2948 envanter numaralı ikinci buluntu28 Aydın ili, Kuyucak ilçesi, Başaran mahallesinde bulunmuş, 07.05.1987 yılında satın alma yoluyla Aydın Arkeoloji Müzesi'ne kazandırılmıştır. Kalın grenli beyaz mermerden dairesel kaide üzerinde, omuzlardan göğüs altına kadar işlenmiş deri zırhlı erkek büstü, gövde ve kaideyle birlikte tek bloktan yontulmuştur (fig. 3a-c). Gövdeye sonradan eklenen portre eksiktir. Boyun çukurunda kırık ve çatlak izleri yer alırken, sağ omuz ve kaideden bir parça kırık ve eksiktir. Yüzey geneline yayllan patina görülebilmektedir. Bir tunik üzerine, merkezinde Medusa başı bulunan lorica giyimli büstün sol omzu üzerinden göğüs üzerine bir epomides sarkmaktadır. Büst, dairesel formlu, iki torus arasında derin bir trokhilos bulunan Ionik kaide ile taşınmaktadır. Kaide ile göğüs arasında yazıtsız tabula yer almaktadır. Menderes Antiokheiası buluntusu büst parçası, lorica giyimli olmasının yanı sıra, göğüs üzerinde Medusa başı betimlenmesi nedeniyle bir imparator büstüne ait olmalıdır.

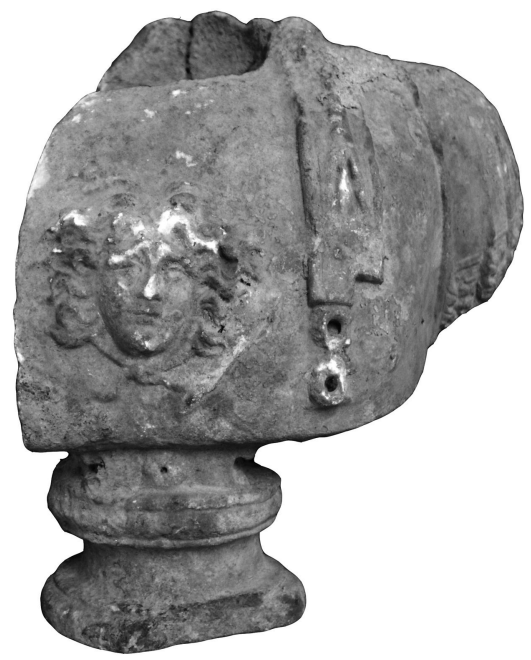

Figür 3a: Büst 2, ön yüz

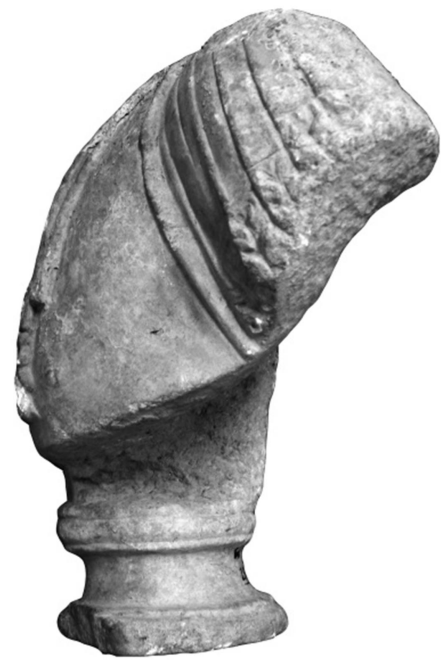

Figür 3b: Büst 2, sol profil

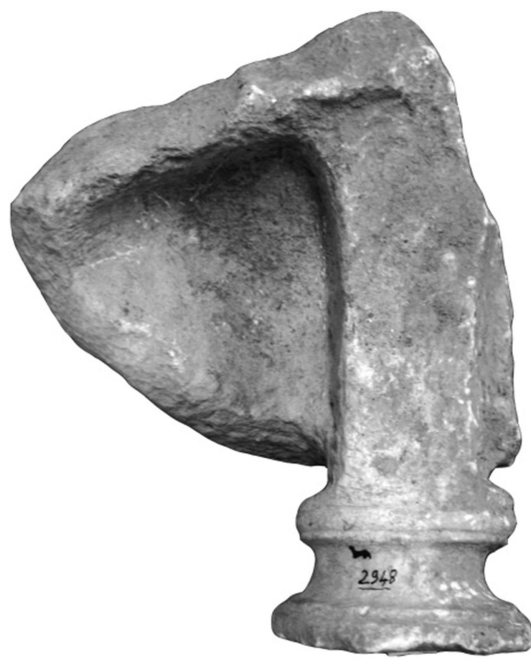

Figür 3c: Büst 2, arka yüz

${ }_{28}$ Ölçüler: Y.: 44,5 cm, G.: 40 cm, K.: 25 cm, Kaide Y.: 10 cm, Kaide Ç.: 18 cm. 
Roma İmparatorluk Dönemi içerisinde Iulius Claudiuslar Dönemi'nden itibaren imparator zırhlı yontu ve büstlerinde Medusa başı betimlemesi bulunmaktadır²9. Bu gelenek, Flaviuslar Dönemi zırhlı portre yontularında sürdürülmüş30, Traianus Dönemi büst ve zırhlı heykellerinde ise yine göğüs kısmında lorica üzerinde Medusa başı, altında antitetik biçimde griphonlar betimlenmiştir ${ }^{31}$. Hadrianus Dönemi büst ve zırhlı heykellerinde de yine göğüs kısmında lorica üzerinde Medusa başı ve Pallas Athena ile her iki yanında Victoria betimlenmektedir ${ }^{32}$. Hadrianus Dönemi'nde bazı örneklerde Traianus Dönemi ile benzer biçimde Medusa başı altında antitetik griphonlar yer almaktadır ${ }^{33}$. Antoninuslar Dönemi'nde de göğüs üzerinde antitetik biçimde konumlandırılan griphonlar ve Medusa başı betimlemeleri yoğun olarak kullanılmıştır ${ }^{34}$. Iulius Claudiuslar Dönemi'nden itibaren zırhlı portre yontusu ve büstler üzerinde betimlenen Medusa başları MS 4. yüzyıla kadar ${ }^{35}$ çok sayıda zırhlı yontu üzerinde farklı biçemlerde görülmektedir. Söz konusu dönemler içerisinde ayırt edici belirteç ise Medusa başlarının betimlenme biçimidir. Antik çă̆ sanatında bedeni olmadan sadece başı ile betimlenen Medusa örnekleri MÖ 5. yüzyılın ortalarından itibaren görülmektedir ${ }^{36}$. Menderes Antiokheiası buluntusu ikinci örnek üzerinde betimlenmiş Medusa başı, dolgun yüz hatlarından ve patetik ifadeden uzak, durağan yapısı ile Roma İmparatorluk Dönemi büst gelişim şeması içerisinde Traianus Dönemi'nde görülen dolgun ve keskin hatlara sahip Medusa baş1 ${ }^{37}$ tasvirlerine karşıt biçimde Hadrianus Dönemi ${ }^{38}$ ile başlayan ve Antoninuslar Dönemi'nde ${ }^{39}$ sürdürülen tipolojiye yakın özelliktedir. Menderes Antiokheiası buluntusu, değinilen özelliklere ek olarak etli ve ağır göz kapakları işlenişiyle Antoninuslar Dönemi özellikleri göstermesine rağmen, Hadrianus ${ }^{40}$ ve Geç Antoninuslar Dönemi ${ }^{41}$ örneklerinde Medusa saçları uzun verilse de yanlarda birbirine dolanan hacimli bukleler " $S$ " formunda dalgalanarak aşağıya uzanmakta ve çene hizasında sonlanmaktadır. İncelediğimiz örnek ise aşağıya sarkmadan yatay düzlemde her iki yana yönlenen ve özellikle sol tarafındaki buklelerde görülen derin ve köprülü matkap kanalları ile ayrılarak alev görünümünde ${ }^{42}$ uçuşan, hareketli ve dalgalı uzun saç düzenlemesiyle, örnekleri Hierapolis tiyatrosu frizlerinde ${ }^{43}$ izlenebilen Severuslar Dönemi stil özelliklerini yansıtmaktadır. Ayrıca Hadrianus ${ }^{44}$ ve Antoninuslar Dönemi'nde ${ }^{45}$ büst kaidelerinin yükselen trokhilos bölümünün Severuslar Dönemi'nde ${ }^{46}$ alçalan formu, Menderes Antiokheiası buluntusu yontu ile benzer yapıdadır. Dolayısıyla incelenen büst parçasının tarihi için Roma İmparatorluk Dönemi içerisinde MS 2. yüzyıl sonları-Erken Severuslar Dönemi- önerilmektedir. Benzer tipteki İzmir Arkeoloji Müzesi'nde yer alan ve Geç Hellenistik Dönem'e tarihlenen 21516 envanter numaralı Metropolis buluntusu zırhlı

29 Özgan 2013, 217, fig. 140a-b.

30 Stemmer 1978, 62, kat. no. V 10.

31 Vermeule 1981, 302, kat. no. 258.

32 Mendel 1914, 316 vd., kat. no. 585.

33 İnan 1974, 649, no. 2, lev. 198-199.

34 Niemeyer 1968, 98, kat. no. 60, lev. 21,1.

35 İnan ve Rosenbaum 1966, 86-87, lev. XLI, no. 3.

36 Dinç ve Durugönül 2015, 167.

37 Poulsen 1974, 65, no. 35, lev. 58-61.

38 İnan ve Rosenbaum 1966, 68-69, no. 29, lev. XIX; Özgür 1996, no. 35.

39 Rosenbaum 1960, 57, kat. no. 47, lev. 34, 3-4.

40 Fittschen ve Zanker 1985, 52, kat. no. 50.

${ }^{41}$ Wegner 1979, 115.

42 Koch 2001, 50.

43 Çubuk 2008, 132-134, fig. 3.1, 3.2.

${ }^{44}$ Lippold 1936, 207, kat. no. 593; Helbig 1963, kat. no. 27.

45 Hinks 1935, 73, fig. 62.

46 İnan ve Rosenbaum 1966, 84, no. 59, lev. XXXVII, 1. 
yontu ${ }^{47}$, herhangi bir motif betimlenmemiş detaylı lorica işlenişi nedeniyle Menderes Antiokheiası örneğine göre erken tarihli olmalıdır. Roma Kapitol Müzesi'nde korunan ve MS 2. yüzyıl sonlarına tarihlenen 463 envanter numaralı Decimus Clodius Septimus Albinus ${ }^{48}$ ve St. Raymond Müzesi'nde yer alan 30113 envanter numaralı Septimus Severus zırhlı büstü49, lorica üzerinde betimlenen Medusa başının dolgun ve yuvarlatılmış hatlardan uzak oval formu, derin kanallı köprülü matkap uygulaması ile birbirinden ayrılan buklelerin yanlara açılarak uçuşan, hareketli ve dalgalı saç düzenlemesi nedeniyle incelediğimiz yontu ile çağdaş olmalıdır. Side Müzesi'nde yer alan ve MS 4. yüzyılın ilk çeyreğine tarihlenen 35 envanter numaralı Side buluntusu Licinius yontusu50, lorica üzerinde betimlenen Medusa başının stilize ve şematik yapısının yanı sıra göğsün daha aşağısında konumlandırılmış olmasıyla Menderes Antiokheiası buluntusundan daha geç olmalıdır.

Büst üzerinde betimlenen Medusa tasvirleri, zırhlı yontuların motifi olmalarının yanı sıra ikonografik açıdan Roma İmparatorluk Dönemi'nde imparatorluğun koruyucusu ve sürekliliğinin güvencesi olarak görülmüştür51. Bu nedenle Medusa tasvirleri dönem modasında sıkça karşımıza çıkmaktadır.

\section{Kabartma Parçası}

Menderes Antiokheiası'ndan 2632 envanter numaralı üçüncü ve son örnek52, bir kabartma parçasıdır. Eser, Aydın ili, Kuyucak ilçesi, Başaran mahallesinde bulunmuş ve 20.01.1981 tarihinde satın alma yoluyla Aydın Arkeoloji Müzesi'ne kazandırılmıştır. Kalın grenli beyaz mermerden yapılmış eser yüksek bir kabartmaya ait olmalıdır (fig. 4). Sadece diş yüzeyinden bir parça korunmuş, diğer kısımlar kırık ve eksiktir. Korunan kisimda boynun solunda

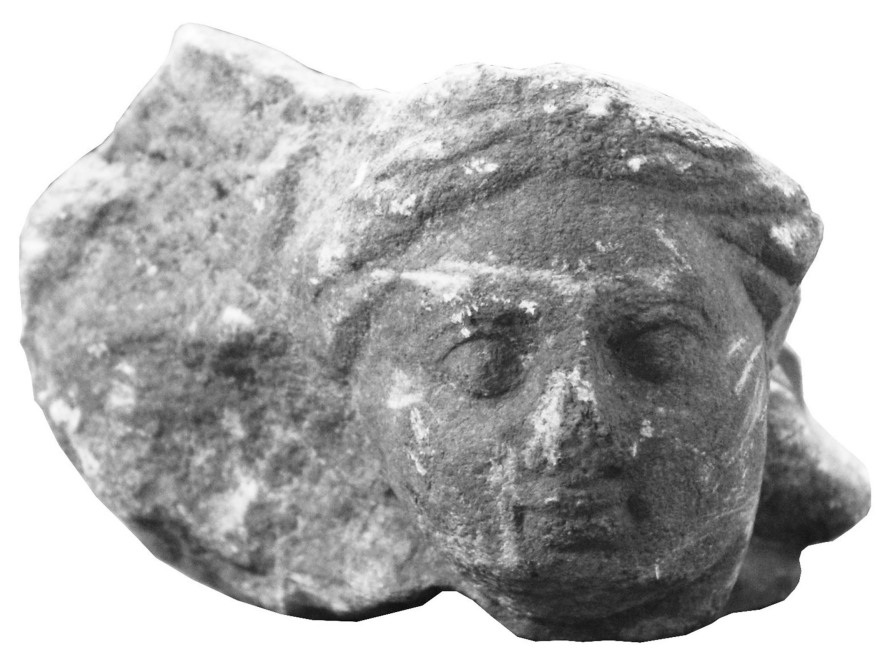

Figür 4: Kabartma parçası el parçası bulunan yüksek kabartma bir erkek başı betimlenmiştir. Gövde, boyundan itibaren kırık ve eksiktir. Yüzey geneline yayılan patina görülmektedir. Dalgalı saçlar alın üzerinde ortadan ikiye ayrıldıktan sonra yanlardan kulakların üst kısminı kapatarak arkaya yönlenmektedir. Yüz, yuvarlak hatlı ve dolgun, alın geniş ve yüksektir, göz kapakları etli verilirken iris ve pupilis işlenmemiştir. Yanaklar dolgun, burun geniş, ağız kapalı, dudaklar dolgun ve çene yuvarlatılmıştır.

Başın doğal yapıda hafifçe dönüşü, uzun ve dalgalı saç modeli, saç-deri geçişinin yumuşak bir hatla işlenmesi, yanakların yumuşak ve dolgun verilmesi, saçların sınırlandırdığ saç buklelerinin yanı sıra karşılaştırma örnekleriyle Menderes Antiokheiası buluntusu kabartma, MÖ 2. yüzyılın ilk yarısının özelliklerini göstermektedir. Berlin Pergamon

47 Aybek 2009, 62 vd., no. 46, lev. 26.

48 Özgan 2015, 33, fig. 13a.

${ }^{49}$ Fittschen ve Zanker 1985, 92, kat. no. 80.

50 İnan ve Rosenbaum 1966, 86-87, lev. XLI, no. 3.

51 Özgan 2013, 195.

52 Ölçüler: Y.: 11 cm, G.: 10 cm, Göz Y.: 1,5 cm, Göz G.: 2 cm, Kab. Y.: 8 cm. 
Müzesi'nde korunan ve MÖ 2. yüzyılın başlarına tarihlenen 135 envanter numaralı Pergamon buluntusu genç erkek portresinin ${ }^{33}$ geniş ve yüksek alın yapısı, büyük ve açık gözlerde dışa taşkın göz küresi ve etli göz kapakları, geniş ve dolgun yanakları ile şişkin ve belirgin elmacık kemiklerinin yanı sıra dolgun dudak yapısı, Antiokheia yontusu ile benzerlik göstermektedir. Ancak Pergamon portresi, III. Alexandros etkisiyle Diadokhlar ve sonrasının dönem modasın $1^{54}$ yansıtan biçimde anastole ve ince kanallarla ayrılarak yüz dokusu ile kontrast oluşturacak düzeyde hareketli ve hacimli bukleler, kırışıklıklar ile hareketlendirilen alın, korunan sol kulağın dışa taşkın yapısı ve sol gözün sağına oranla daha yükseğe yerleştirilmesi ile vurgulanan asimetrik yüz hatlarının yansıttığı patetik ifade nedeniyle Antiokheia yontusundan erken tarihli olmalıdır. Aydın Arkeoloji Müzesi'nde korunan ve MÖ 2. yüzyılın ilk yarısına tarihlenen 37 envanter numaralı yayınlanmamış Apollon Kitharodos tipindeki yontu55, saç-deri geçişinin yumuşak işlendiği, alın üzerinde ortadan ikiye ayrılan uzun, dalgalı ve hacimli saçların kulakların üst kısmını kapatarak arkaya yönlenen yapısı, saçların sınırlandırdığı üçgen formlu geniş ve yüksek alın, geniş ve dolgun yanaklarda şişkin ve belirgin elmacık kemikleri, badem formlu gözlerde göz küresinin dışa taşkın biçimde belirgin yapısı, hareketli ve dolgun dudak yapısına sahip küçük ve kapalı ağzı ile yumuşak hatlı verilen yuvarlatılmış dolgun ve geniş çene yapısı bakımından Menderes Antiokheiası buluntusu örnekle oldukça benzer özellikler göstermekte, dolayısıyla bu iki eser çağdaş olmalıdır. Berlin Pergamon Müzesi'nde korunan ve MÖ 2. yüzyıla tarihlenen 784 envanter numaralı Halikarnassos buluntusu mezar stelinde betimlenen erkek yontusu baş156, Geç Hellenistik Dönem özellikleri yansıtan durağan ifade, kısa saç modeli ve dışa taşkın alın yapısının yanı sıra küçük ve kısık göz işlenişi nedeniyle Menderes Antiokheiası örneğinden daha geç olmalıdır.

\section{Değerlendirme ve Sonuç}

Büyük Menderes Vadisi yerleşimlerinden Menderes Antiokheiası, Plinius'un aktardığı bilgilere göre Symmathios ve Kranaos'un birleşimi ile -synoikismosoluşturulmuştur (Plin. nat. V, 108). Özellikle bu bölgede MÖ 3. yüzyıldaki Seleukhosların hâkimiyetiyle birlikte başlayan sanat gelişimi daha sonra MÖ 2. yüzyılda da devam etmiştir ${ }^{57}$. MÖ 190 yılında Seleukhoslar ile Pergamon desteğindeki Roma Cumhuriyeti güçlerinin Sipylum Magnesiası'nda gerçekleşen Magnesia Savaş158 ve sonrasında MÖ 188 yılında imzalanan Apameia Barış Antlaşması'yla birlikte Batı Anadolu'nun büyük bir kısmı Attalos Krallı̆̆g'nın idaresi altına girmiştir59. Bu kapsamda özellikle II. Eumenes Dönemi'ndeki II. Pergamon Heykeltıraşlık Okulu'nun etkisiyle Batı Anadolu ve adalardaki heykeltıraşlık üretiminde Pergamon ekolüne bağlı olarak bir gelişim ve artış görülmektedir ${ }^{60}$. Bu ekolün Karia Bölgesi'ndeki en belirgin etkisi Menderes Magnesiası ${ }^{61}$ ve Tralleis ${ }^{62}$ antik kenti heykeltıraşlık eserlerinde karşımıza çıkmaktadır. Menderes Antiokheiası buluntusu kabartma parçasının yüksekliği, II. Eumenes Dönemi'ndeki friz geleneğine $^{63}$ yakın görünmektedir. Erkek figürü, uzun ve dalgalı saçlarının yanlara doğru taranması nedeniyle Pergamon ekolünde, daha çok II. Eumenes Dönemi özelliklerini

\footnotetext{
53 Winter 1908, 154, no. 135.

54 Özgan 2016a, 39.

55 Apollon Kitharodos tipinde yontu üst gövde parçası, Aydın Arkeoloji Müzesi Taş Eserler Deposu, env. no. 37.

56 Pfuhl ve Möbius 1977, 86, no. 141, lev. 32.

57 Özgan 1982a, 3.

58 Ruge 1937, 2102; Üreten 2005, 201-202.

59 Kaya 2016, 241-242.

60 Özgan 2016b, 10.

61 Özgan 1982b, 197 vd.

62 Özgan 1982a, 1 vd.; Şahan 2006, 1 vd.; Dinç 2013, 1 vd.; Dinç 2019, 127-132; Çekilmez 2016, 297-322.

63 Smith 2013, 161 vd.; Özgan 2018, 155 vd.
} 
göstermektedir. Menderes Antiokheiası kabartmasındaki figür, saçlarının uzun ve dalgalı işlenmesi nedeniyle MÖ 160/150 civarına tarihlenen Telephos Frizi ${ }^{64}$ kabartmalarındaki erkek figürlerinden daha erken özellikler göstermektedir. Bunun yanında figürün yuvarlak yüz yapısı, büyük ve açık gözleri, etli göz kapakları, şişkin elmacık kemikleri ve küçük kapalı ağız yapısıyla birlikte yuvarlak formlu çenesi, II. Eumenes Dönemi'ndeki Pergamon ekolünün devam ettiğini gösteren özellikleridir.

MÖ 126 yılındaki Aristonikos Ayaklanması ${ }^{65}$ ve MÖ 88 yılındaki Pontus Kralı VI. Mithridates Eupator'un Roma Cumhuriyeti'ne karşı başlattı̆̆ 1 ayaklanmalar ${ }^{66}$ nedeniyle MÖ 2. yüzyılın son çeyreğinden MÖ 1. yüzyılın ilk yarısına kadar bölgedeki heykeltıraşlık eserlerinde azalma görülmüştür ${ }^{67}$. Daha sonra Iulius Claudiuslar Dönemi ve sonrasında gelişen ekonomiyle birlikte heykeltıraşlık eserlerinde de artış gözlenmektedir ${ }^{6}$. R. Özgan, Tralleis heykeltıraşlık eserlerini ele aldığı çalışmasında, Tralleis ekolünün Flaviuslar Dönemi sonuyla birlikte etkisini yitirmeye başladığını ve Aphrodisias'ın gölgesinde kalarak, Karia Bölgesi heykeltıraşlığının Aphrodisias'ın egemenliğinde sürdürüldüğünü aktarmaktadır ${ }^{69}$. H. P. Laubscher, Hellenistik Dönem boyunca süreklilik gösteren Tralleis ekolünün, Roma İmparatorluk Dönemi'nde gelişen Aphrodisias ekolünün kuruluşuna yardımcı olduğu ve bu ekolün ortaya çıkmasında önemli bir rol oynadığ1 düşüncesindedir ${ }^{70}$. Aphrodisias atölyelerinde Roma İmparatorluk Dönemi'nde -MS 1. yüzyıldan Geç Antik Çağ içlerine kadar- çok sayıda portre heykeli yanında kamusal alanlar, konutlar ve mezar odalarında sergilenmek üzere imparator, rahip, filozof ve privat portre temsili olarak erkek ve kadın büst yontuları da üretilmiştir71. Genel büst tipolojisinde olduğu gibi Aphrodisias atölyelerinde de büstler, prestij sembolü olarak bireyin imajını yansıtan biçimde sergileme alanlarında genellikle göz düzleminde konumlandırıldıkları için ayrıntıları vurgulanan biçimde işlenirken, üst gövdenin arkasında derin bir girintiyle oluşturulan omurga işlevinde destek yer almaktadır ${ }^{72}$. Menderes Antiokheiası buluntusu iki büst parçası; lokalizasyon olarak oldukça yakınında yer alan ve özellikle incelenen ilk büst parçasında görüldüğü üzere yoğun raspa uygulaması sonrasında pürüzsüzleştirilerek parlatılan cilalı görünümlü üst gövdede boyun başlangıcında izlenen detaylı köprücük kemiği işçiliği ile Aphrodisias Hadrianus Hamamları ve Atrium Evi buluntusu büst örnekleriyle ${ }^{73}$ benzer özelliktedir. Ayrıca Menderes Antiokheiası buluntusu ikinci büst üzerinde betimlenen Medusa başı, buklelerinin başın sol tarafında düzenli biçimde birbirinden ayrılması, sağ tarafında ise kulak düzleminden çene kısmına uzanan kalın ve geniş yüzeyli buklelerin çatallanarak sivrilen uçları, Aphrodisias Batı Nekropolisi buluntusu girlandlı bir lahit ${ }^{74}$ ile Aydın Arkeoloji Müzesi'nde sergilenen ve Aphrodisias atölyesine atfedilen 1489 envanter numaralı Harpasa Lahdi $^{75}$ üzerinde yer alan Medusa başının saç düzenlemesi ile benzer stil özelliği yansıtmaktadır. Dolayısıyla Menderes Antiokheiası buluntusu iki büst parçası, çok sayıda büst üretimiyle bilinen Roma İmparatorluk Dönemi Aphrodisias heykeltıraşlık atölyeleri ekolüne ait olmalıdır. Bu düşünceyi destekler şekilde Menderes Antiokheiası buluntusu olan

\footnotetext{
64 Smith 2013, 168 vd.

65 Ruge 1937, 2104.

66 Ruge 1937, 2104.

67 Özgan 1990, 251 vd.

68 Özgan 2013, 147 vd.

69 Özgan 1982a, 3, 165.

70 Laubscher 1966, 127; Özgan 1982a, 165.

71 Smith, 2008, 11 vd.

72 Smith 2008, 13.

73 Smith 2008, 11, 20, no. 3, 22.

74 Erim 2000, 69, no. 100.

75 Strocka 1996, 473, fig. 45.
} 
Roma İmparatorluk Dönemi'ne ait lahit parçası (fig. 1), Strocka ${ }^{76}$ ve Işık ${ }^{77}$ tarafından, Aphrodisias ekolü içerisinde girlandlı lahitler grubunda incelenmiştir. Sonuç olarak bu çalışmada üç örnek değerlendirilmiş ve bu doğrultuda kentin Hellenistik ve Roma İmparatorluk Dönemi heykeltıraşlık eserleri öznelinde bölge arkeolojisi literatürüne katkıda bulunulması amaçlanmıştır. Ancak Menderes Antiokheiası buluntusu heykeltıraşlık eserlerinin stil özeliklerinin belirlenebilmesi için kazı buluntusu olan ve konteksti bilinen daha çok plastik buluntu, bu konuda bilgilerimizin artmasını sağlayacaktır.

\section{Figürlerin Listesi:}

Figür 1: Aydın Arkeoloji Müzesi'nden Menderes Antiokheiası buluntusu lahit parçası (U. Kapuci)

Figür 2a: Büst 1, ön yüz (U. Kapuci)

Figür 2b: Büst 1, sağ profil (U. Kapuci)

Figür 2c: Büst 1, sol profil (U. Kapuci)

Figür 2d: Büst 1, arka yüz (U. Kapuci)

Figür 3a: Büst 2, ön yüz (U. Kapuci)

Figür 3b: Büst 2, sol profil (U. Kapuci)

Figür 3c: Büst 2, arka yüz (U. Kapuci)

Figür 4: Kabartma parçası (U. Kapuci)

${ }^{76}$ Strocka 1996, 467, fig. 29

77 Işık 2007, kat. no. 28f, lev. 28-8. 


\section{Bibliyografya}

Aybek, S. (2009). Metropolis İonia I-Heykel. Metropolis'de Hellenistik ve Roma Dönemi Heykeltıraşlı̆̆ı. Homer Kitabevi ve Yayıncılık.

Chandler, R. (1775). Travels in Asia Minor: or An Account of a Tour Made at the Expense of the Society of Dilettanti. Clarendon Press.

Çekilmez, M. (2016). Tralleis'ten Bir Eros Yontusu. OLBA, XXIV, 297-322.

Çubuk, N. (2008). Hierapolis Tiyatro Kabartmaları. Arkeoloji ve Sanat Yayınları.

Dinç, R. (2011). Antiokheia Ad Maeandrum Yakınındaki Roma Köprüsü. A. Öztan ve Ş. Dönmez (Ed.) Karadeniz'den Fırat'a Bilgi Üretimleri, Önder Bilgi'ye Armağan Yazıları. (ss. 111128). Bilgin Kültür Sanat Yayınları.

Dinç, M. (2013). Tralleis Heykeltıraşlık Eserleri 1996-2002 Kazılarında Ele Geçen Hellenistik ve Roma Dönemi Mermer Heykeltıraşlık Buluntuları. [Yayımlanmamış Doktora Tezi]. Mersin Üniversitesi.

Dinç, M. (2019). Tralleis'ten Grotesk Figürlü Masa Ayakları. T. Demir, M. Ekici, M. ŞahanDinç ve Ç. M. Tarhan (Eds.), Rifat Ergeç Armağanı (ss. 127-132). Bilgin Kültür Sanat Yayınları.

Dinç, M. ve Durugönül, S. (2015). Manisa Müzesi'ndeki Hermeler ve Bir Duvar Aplik'i. S. Durugönül (Ed.) Manisa Müzesi Heykeltıraşlı Eserleri (ss. 157-162). Oksijen Basım ve Matbaacilik.

Erim, K. T. (2000). Aphrodisias. Net Yayın.

Fittschen, K. ve Zanker, P. (1985). Katalog der romischen Portrats in den Capitolinischen Museen und den anderen kommunalen Sammlungen der Stadt Rom 1. Kaiser- und Prinzenbildnisse. BeitrESkAr 3. Philipp von Zabern.

Fittschen, K., Zanker, P. ve Cain, P. (2010). Katalog der römischen Portraits in den Capitolinischen Museen und den anderen kommunalen Sammlungen der Stadt Rom. Die mannlichen Privatportrats 2. BeitrESkAr 4. Philipp von Zabern.

Hamilton, W. J. (1842). Researches in Asia Minor, Pontus and Armenia, with Some Account of Their Antiquities and Geology, Vol. 1-2. John Murray.

Helbig, W. (1963). Führer durch die öffentlichen Sammlungen klassischer Altertümer in Rom. E. Wasmuth.

Hinks, R. P. (1935). Greek and Roman Portrait Sculpture. British Museum.

Işık, F. (2007). Girlanden- Sarkophage aus Aphrodisias. Sarkophag-Studien 5, Philipp von Zabern.

İnan, J. (1974). Neue Porträtstatuen aus Perge. Mansel'e Armağan II (ss. 643-661). Türk Tarih Kurumu Basimevi.

İnan, J. ve Rosenbaum, E. (1966). Roman and Early Byzantine Portrait Sculpture in Asia Minor. Oxford University Press.

Kaya, M. A. (2016). İlk Çă̆ Tarihi ve Uygarlı̆̆ı. Pegem Akademi. 
Koch, G. (2001). Roma Imparatorluk Dönemi Lahitleri. Arkeoloji ve Sanat Yayınları.

Laubscher, H. P. (1966). Skulpturen aus Tralles, Zu einem neuen Zweifigurenrelief. IstMitt $16,115-129$.

Leake W. M. (1824). A Journal of a Tour in Asia Minor, with Comparative Remarks on the Ancient and Modern Geography of that Country. John Murray.

Lippold, G. (1936). Die Skulpturen des Vaticanischen Museums 3, 1. De Gruyter.

Mendel, G. (1914). Musées Impériaux Ottomans. Catalogue des Sculptures Grecques, Romaines et Byzantines II, İstanbul.

Niemeyer, H. G. (1968). Studien zur Statuarischen Darstellung der Romischen Kaiser. Gebr. Mann Verlag.

Özgan, R. (1982a). Yunan ve Roma Devri Tralleis Heykeltıraşlığı. [Doçentlik Tezi]. Selçuk Üniversitesi, Konya.

Özgan, R. (1982b). Zur Datierung des Artemisaltars in Magnesia am Maeander. IstMitt, 32, 196-209.

Özgan, R. (1990). İ.S. 1. Yüzyıl Tralleis Yontuculuğu. X. Türk Tarih Kongresi (ss. 247-284). Türk Tarih Kurumu Yayınları.

Özgan, R. (1999). Die Skulpturen von Stratonikeia. Asia Minor Studien 32, R. Habelt.

Özgan, R. (2013). Roma Portre Sanatı II. Ege Yayınları.

Özgan, R. (2015). Roma Portre Sanatı III. Ege Yayınları.

Özgan, R. (2016a). Hellenistik Devir Heykeltıraşlı̆̆ı I. Büyük İskender'den Diadochlar Sonrasına. Arkeoloji ve Sanat Yayınları.

Özgan, R. (2016b). Hellenistik Devir Heykeltıraşlı̆̆ı II. Erken Hellenistikten Yüksek Hellenistiğge. Arkeoloji ve Sanat Yayınları.

Özgan, R. (2018). Hellenistik Devir Heykeltıraşhı̆ğ III. Yüksek Hellenistik. Arkeoloji ve Sanat Yayınları.

Özgür, M. E. (1996). Skulpturen des Museums von Antalya I. Dönmez Offset Basımevi.

Pfuhl, E. ve Möbius, H. (1977). Die Ostgriechischen Grabreliefs I. Von Zabern.

Poulsen, V. (1974). Les Portraits Romains II. De Vespasien a la Basse-Antiquite, Glyptotheque Ny Carlsberg.

Pozzi, E. (1989). Le Collezioni del Museo Nazionale di Napoli I 2. La scultura greco-romana, le sculture antiche della collezione Farnese, le collezioni monetali, le oreficerie, la collezione glittica, De Luca.

Rosenbaum, E. (1960). Cyrenaican Portrait Sculpture. British Academy.

Ruge, W. (1937). Tralleis. Realencyclopädie der Classischen Altertumswissenschaft, 6, 2094-2128. 
Saraçoğlu A. ve Üreten, H. (2012). Antik Dönemde Aydın ve Çevresindeki Kentler. S. Yaylalı (Ed.) Aydın Il Tarihi (ss. 57-98). Özyurt Matbaacılık.

Smith, R. R. R. (2008). Aphrodisias'ta Yapılan Roma Portreleri ve Mermer Heykeltıraşlık. R.R.R. Smith ve J. L. Lenaghan (Eds.) Aphrodisias'tan Roma Portreleri (ss. 9-33). Yap1 Kredi Yayinları.

Smith, R. R. R. (2013). Hellenistik Heykel. Homer Kitabevi ve Yayıncllık.

Smith, R. R. R. ve Ratté, C. (1996). Archaeological Research at Aphrodisias in Caria, 1994. AJA, 100(1), 5-33. https:// doi.org/10.2307/506295

Söner, R. H. (2017). Antiokheia ad Maeandrum Antik Kenti. Humanitas, 5(9), 139-153. https://doi.org/10.20304/humanitas.318518

Stemmer, K. (1978). Untersuchungen zur Typologie, Chronologie und Ikonographie der Panzerstatuen, AF 4, Mann.

Strocka, V. M. (1996). Datierungskritierien kleinasiatischer Girlandensarkophage. AA, 3, 455473.

Stuart-Jones, H. (1912). A Catalogue of the Ancient Sculptures preserved in the Municipal Collections of Rome, The Sculptures of the Museo Capitolino. Clarendon Press.

Şahan, M. (2006). Yeni Tralleis Kazılarından Bulunan Hamam Rölyefleri. [Yayımlanmamış Yüksek Lisans Tezi]. Adnan Menderes Üniversitesi.

Üreten, H. (2005). Roma Dönemi'ne Kadar Tralleis Tarihi ve Attaloslar ile İlişkileri. Tarih Araştırmaları Dergisi, 24(38), 195-212. https://doi.org/10.1501/Tarar_0000000241

Vermeule, C. C. (1981). Greek and Roman Sculpture in America, University of California Press.

Wegner, M. (1979). Verzeichnis der Kaiserbildnisse von Antoninus Pius bis Commodus. Boreas, 2, 87-181.

Winter, F. (1908). Die Skulpturen mit Ausnahme der Altarreliefs. AvP VII.I. Verlag von Georg Reimer.

Wünsche, R. (2007). Glyptothek, Munich, Masterpieces of Greek and Roman Sculpture. Beck C. H.

Yıldırım, N. (2012). Herakles Hermelerinin Anlamı ve Kullanımı. Mediterranean Journal of Humanities 2(1), 229-237. 